\title{
Hubungan Kadar Timbal (Pb) dengan Kadar Malondialdehid (MDA) dalam Darah pada Ibu Hamil di Wilayah Pantai Kabupaten Brebes
}

\author{
Hari Ismanto ${ }^{1}$ \\ ${ }^{1}$ Bagian Kesehatan Lingkungan, Fakultas Kesehatan Masyarakat, Universitas Diponegoro \\ Info Artikel : Diterima 17 Januari 2019 ; Disetujui 13 Maret 2019 ; Publikasi 29 April 2019
}

\begin{abstract}
ABSTRAK
Latar Belakang : Kematian ibu di Jawa Tengah tertinggi ditemukan di Kabupaten Brebes dengan jumlah kasus sebesar 54 kasus pada 2016 dan 52 kasus pada 2015. Paparan timbal dimungkinkan menjadi penyebabnya. Penelitian ini dilakukan di 4 wilayah pesisir Kecamatan di Brebes. Tujuan dari penelitian ini adalah untuk menentukan hubungan antara kadar timbal $(\mathrm{Pb})$ dengan kadar malondialdehyde (MDA) dalam darah ibu hamil. Metode : Penelitian ini merupakan jenis penelitian observasional analitik dengan desain Cross Sectional. Sampel adalah ibu hamil yang berjumlah 85 orang. Data dianalisis secara deskriptif dengan analisis univariat, data mengenai kadar Pb dan MDA dianalisis dengan uji hubungan Rank-Spearman.

Hasil : Hasil penelitian menunjukkan bahwa rerata usia ibu hamil adalah 30,15 tahun dengan rentang usia terbesar adalah 20-35 tahun. Rerata usia kehamilan adalah 27,62 minggu atau dominan berada pada trimester 2 dan 3 kehamilan $(43,5 \%$ dan 54,1\%). Ibu hamil dalam penelitian ini adalah orang yang berisiko tinggi terpapar tembakau dan pestisida (28,2\% dan 78,8\%). Rerata kadar timbal dalam darah ibu hamil sebesar $42.67 \mu \mathrm{g} / \mathrm{dl}$ dan MDA sebesar $377.3 \mathrm{ng} / \mathrm{ml}$. Hasil uji hubungan antara kadar timbal dan kadar MDA dalam darah ibu hamil menunjukkan tidak adanya hubungan yang signifikan $(\mathrm{p}>0,05)$.

Simpulan : Kadar timbal dalam darah di wilayah ini dapat dikaji lebih dalam. Ibu hamil disarankan untuk mencegah terkena paparan timbal dengan menghindari asap rokok, pestisida, tidak mengkonsumsi makanan yang terkontaminasi timbal, dan meminimalkan paparan asap kendaraan.
\end{abstract}

Kata Kunci : Timbal, malondialdehyde, ibu hamil, Kabupaten Brebes

\section{ABSTRACT \\ Title : The Association of Lead Levels and Malondialdehyde Levels of Pregnant Woman in Coastal Area of Brebes District}

Background : The highest maternal mortality in Central Java was found in Brebes District with 54 cases in 2016 and 52 cases in 2015. Lead exposure may contribute to the causes. The study was conducted in four coastal areas of sub-districts in Brebes. The purpose of this study was to determine the relationship between lead $(\mathrm{Pb})$ levels with malondialdehyde $(\mathrm{MDA})$ levels of pregnant women's blood.

Method : It was an observational analytic research with a cross sectional study design. The samples were 85 pregnant women. Data were analyzed descriptively by univariate analysis, data on lead levels and malondialdehyde levels were analyzed using Rank Spearman correlation test.

Result : The study showed that the average age of pregnant women was 30.15 years old with the largest age category being 20-35 years. The average gestational age was 27.62 weeks or predominantly in the second and third trimesters of pregnancy $(43.5 \%$ and $54.1 \%)$. The pregnant women in the study area had high risk of lead exposure sourced from cigarette and pesticides $(28.2 \%$ and $78.8 \%)$. The average lead level in the blood of pregnant women is $42.67 \mu \mathrm{g} / \mathrm{dl}$, while malondialdehyde was $377.3 \mathrm{ng} / \mathrm{ml}$. The results of the correlation test of lead levels with malondialdehyde levels in the blood of pregnant women showed that both variables were not related ( $p$ Value>0.05).

Conclusion : It is important to highlight the lead levels of blood in the study area. Pregnant women are advised to prevent lead exposure by avoiding cigarette smoke, pesticides, not consuming lead contaminated seafood, and minimizing the vehicle emission exposure.

Keywords : Lead, Malondialdehyde, Pregnant women, Brebes District

\section{PENDAHULUAN}

Kasus kematian ibu tertinggi di Jawa Tengah adalah Kabupaten Brebes dengan 54 kasus pada tahun 2016. AKI pada Kabupaten Brebes pada tahun 2015 sebesar 156 per 100.000 kelahiran hidup atau sebanyak 52 kasus, mengalami 
penurunan bila dibandingkan dengan angka kematian ibu pada tahun 2014 sebesar 218,20 per 100.000 kelahiran hidup dengan kasus sebanyak 73. ${ }^{1,2}$ Salah satu penyebabnya adalah adanya paparan timbal.

Timbal merupakan logam beracun yang digunakan secara luas serta dapat menyebabkan kerusakan lingkungan dan menyebabkan masalah bagi kesehatan. Timbal adalah racun yang dapat bersifat kumulatif, artinya paparannya akan menumpuk dalam tubuh manusia, ${ }^{3}$ dan dapat mengakibatkan gangguan kesehatan berupa anemia, gangguan fungsi ginjal, gangguan sistem syaraf dan otak dan kulit. ${ }^{4}$ Berbagai penelitian telah melaporkan gangguan kesehatan yang disebabkan oleh pencemaran timbal, WHO memperkirakan bahwa pada tahun 2004, paparan timbal telah menyebabkan 143.000 kasus kematian di seluruh dunia, dan 0,6\% dari kasus kecacatan di dunia disebabkan oleh paparan timbal. Selain itu, paparan timbal juga menyebabkan gangguan mental dan kerusakan pada sistem kardiovaskular. ${ }^{3}$

Paparan timbal menyebabkan gangguan janin yang sedang berkembang dan peningkatan tekanan darah tinggi selama kehamilan. Wanita dengan tingkat timbal yang tinggi dalam tubuh mereka sebelum atau sesudah kehamilan juga akan beresiko memaparkan ke janin melalui plasenta. ${ }^{5}$ Oleh karena itu, peningkatan kadar timbal dalam darah pada wanita hamil adalah masalah kesehatan bagi ibu dan anak. Selama kehamilan, paparan timbal telah dikaitkan dengan peningkatan risiko hipertensi gestasional. ${ }^{6,7}$ Wanita hamil yang terpapar timbal dalam dosis tinggi, pada kondisi akut dapat terjadi keguguran, lahir premature, kematian janin, bayi lahir dengan bobot rendah, maupun bayi lahir cacat. ${ }^{3}$

Timbal dapat berperan sebagai radikal bebas atau oksidan dalam tubuh. Jika terjadi ketidakseimbangan jumlah oksidan dan antioksidan dalam tubuh, dapat berupa penurunan kadar antioksidan dan/atau peningkatan kadar oksidan, maka akan terjadi kondisi stres oksidatif. ${ }^{8}$ Salah satu marker dari stress oksidatif adalah aktifitas lipid peroksidase yang bisa diukur dari kadar Malondialdehyde (MDA) dalam organ. Malondialdehyde (MDA) merupakan senyawa yang dapat menggambarkan aktivitas radikal bebas di dalam sel sehingga dijadikan sebagai salah satu petunjuk terjadinya stres oksidatif akibat radikal bebas. ${ }^{9}$ Produk radikal bebas ini dapat ditemukan di hampir seluruh cairan biologis tubuh. ${ }^{10}$
Paparan timbal sangat berpengaruh pada derajat kesehatan masyarakat di Kabupaten Brebes. Penelitian sebelumnya menunjukkan bahwa ratarata kadar timbal dalam darah wanita hamil di Kabupaten Brebes sudah berada diatas ambang batas aman. Hal ini berpotensi munculnya berbagai gangguan kehamilan, beberapa diantaranya melibatkan mekanisme stress oksidatif. Oleh karena itu, perlu adanya penelitian untuk mengetahui hubungan kadar timbal dan stress oksidatif pada wanita hamil di Kabupaten Brebes.

\section{MATERI DAN METODE}

Jenis penelitian ini merupakan penelitian analitik observasional dengan rancangan studi cross sectional. Populasi target penelitian ini adalah seluruh ibu hamil di 6 wilayah kerja puskesmas yaitu Puskesmas Wanasari, Puskesmas Kluwut, Puskesmas Bulakamba, Puskesmas Tanjung, Puskesmas Kecipir, dan Puskesmas Losari sebanyak 1734 orang. Penentuan sampel pada penelitian ini adalah dengan purposive sampling. Besar sampel minimal dihitung dengan rumus:

$$
n=\frac{Z_{1-\frac{\alpha}{2}}^{2} P(1-P) N}{(d)^{2}(N-1)+Z_{1-\frac{\alpha}{2}}^{2} P(1-P)}
$$

Hasil perhitungan mendapatkan besar sampel minimal dalam penelitian ini adalah 90 ibu hamil. Pemeriksaan kadar timbal dalam darah dilakukan menggunakan metode AAS (Atomic Absorbtion Spectrofotometry). Pemeriksaan kadar Malondialdehid menggunakan metode TCA (Trichloroacetic acid). Wawancara terhadap responden menggunakan kuesioner terstruktur. Wawancara dilakukan untuk mengetahui riwayat paparan timbal yang meliputi riwayat terpapar pestisida, asap rokok dan jumlah asupan gizi harian. Data yang terkumpul diolah dan dianalisis secara deskriptif yang berupa distribusi frekuensi dan sebaran data. Data kadar timbal dan kadar malondialdehid dalam darah dianalisis korelasi menggunakan uji Rank Spearman.

\section{HASIL DAN PEMBAHASAN \\ Karakteristik Responden}

Penelitian dilaksanakan dalam dua tahap, yakni tahap pengambilan sampel darah dan tahap wawancara lanjutan. Sejumlah 116 ibu hamil berpartisipasi sebagai subjek penelitian dan hadir saat pengambilan sampel, namun hanya 85 sampel yang berhasil diperiksa kadar malondialdehid.

Tabel 1. Karakteristik Responden

\begin{tabular}{clccccc}
\hline No. & \multicolumn{1}{c}{ Variabel } & $\mathrm{n}$ & $\%$ & Rerata (SD) & Median & Min - Max \\
\hline 1. & Umur Ibu (tahun) & 85 & 100 & $30,15(5,27)$ & 30,00 & $19-41$ \\
2. & $\begin{array}{l}\text { Kategori Umur Ibu } \\
\text { a. }<20\end{array}$ & 5 & 5,9 & & & \\
\hline
\end{tabular}




\begin{tabular}{|c|c|c|c|c|c|c|}
\hline & b. $20-35$ & 63 & 74,1 & & & \\
\hline & c. $>35$ & 17 & 20 & & & \\
\hline 3. & Umur Kehamilan (minggu) & 84 & 98,8 & $27,62(7,34)$ & 28,00 & $10-40$ \\
\hline \multirow[t]{4}{*}{4.} & Kategori Umur Kehamilan & & & & & \\
\hline & a. Trimester 1 & 1 & 1,2 & & & \\
\hline & b. Trimester 2 & 37 & 43,5 & & & \\
\hline & c. Trimester 3 & 46 & 54,1 & & & \\
\hline \multirow[t]{7}{*}{5.} & Tingkat Pendidikan & & & & & \\
\hline & a. Tidak Sekolah & 3 & 3,5 & & & \\
\hline & b. SD & 41 & 48,2 & & & \\
\hline & c. SMP & 26 & 30,6 & & & \\
\hline & d. SMA & 9 & 10,6 & & & \\
\hline & e. PT & 4 & 4,7 & & & \\
\hline & f. Lain-Lain & 1 & 1,2 & & & \\
\hline \multirow[t]{5}{*}{6.} & Pekerjaan Ibu & & & & & \\
\hline & a. Ibu Rumah Tangga & 64 & 75,3 & & & \\
\hline & b. Karyawan Swasta & 3 & 3,5 & & & \\
\hline & c. Buruh Tani & 11 & 12,9 & & & \\
\hline & d. Lain-lain & 6 & 7,1 & & & \\
\hline \multirow[t]{7}{*}{7} & Pekerjaan Suami & & & & & \\
\hline & PNS & 1 & 1,2 & & & \\
\hline & Karyawan Swasta & 10 & 11,8 & & & \\
\hline & Petani Pemilik & 2 & 2,4 & & & \\
\hline & Buruh Tani & 20 & 23,5 & & & \\
\hline & Nelayan & 8 & 9,4 & & & \\
\hline & Lain-lain & 43 & 50,6 & & & \\
\hline
\end{tabular}

Pada tabel 1 dapat diketahui bahwa rerata umur ibu adalah 30,15 tahun. Sebanyak 5 orang ibu berusia dibawah 20 tahun (5,9\%), 63 orang ibu berusia antara 20-35 tahun $(74,1 \%)$, dan sebanyak 17 orang ibu berusia lebih dari 35 tahun (20\%). Berdasarkan umur kehamilan pada saat pengambilan sampel darah, usia kehamilan paling banyak pada trimester kedua yaitu 62 responden $(55,4 \%)$. Sedangkan umur kehamilan ibu rata-rata pada kehamilan trimester 1 sebanyak 2 responden $(1,8 \%)$ dan trimester 3 sebanyak 48 responden $(42,9 \%)$, Namun ada 1 responden yang tidak mengisi umur kehamilannya sehingga pada kategori umur kehamilan ini ada 1 data missing. Sebanyak $41 \mathrm{ibu}$ hamil berpendidikan lulus SD $(48,2 \%)$, diikuti tingkat pendidikan lulus SMP 26 orang $(30,6 \%)$. Dilihat dari segi pekerjaan, mayoritas ibu hamil adalah ibu rumah tangga (64 orang, 75,3\%), 11 orang bekerja sebagai buruh tani $(12,9 \%)$. Namun, pekerjaan suami sebagai buruh tani cukup banyak yakni sejumlah 20 orang $(23,5 \%)$.

\section{Sumber Paparan Timbal di Wilayah Penelitian}

Penelitian ini dilakukan di 4 kecamatan di Kabupaten Brebes, dimana keempat kecamatan tersebut merupakan wilayah pantai yang berbatasan langsung dengan laut jawa. Hal ini tentu saja sangat berhubungan dengan pasokan makanan yang berasal dari laut. Data dari BPS tahun 2018 menyebutkan bahwa penduduk di empat kecamatan tersebut yang berprofesi sebagai nelayan cukup banyak. Penduduk Kecamatan Bulakamba yang bekerja sebagai nelayan sejumlah 8.802 orang, ${ }^{11}$ Kecamatan Tanjung 2.621 orang, ${ }^{12}$ dan Kecamatan Wanasari terdapat 5.745 orang. ${ }^{13}$

Hasil laut yang tercemar logam timbal akan meningkatkan resiko paparan timbal kepada manusia. laporan dari Suyanto, dkk. tahun 2010 menyebutkan bahwa ikan dari sampel yang diperiksa yang berasal dari wilayah laut Kabupaten Tegal, Pati dan Semarang mengandung timbal dengan konsentrasi $<0,1$ sampai $0,14 \mathrm{ppm} .{ }^{14}$ ikan dan hasil laut lain yang mengandung timbal kemudian dikonsumsi manusia, maka kandungan timbal tersebut akan berpindah kedalam tubuh manusia. bila hal ini berlangsung dalam jangka waktu yang lama, maka timbal akan terakumulasi dalam tubuh manusia dalam jumlah yang terus meningkat.

Selain potensi paparan timbal dari hasil perikanan laut, ibu hamil di wilayah penelitian juga berpotensi terpapar dari kegiatan pertanian. Data BPS Kabupaten Brebes menyebutkan sebagian besar penduduk kabupaten ini bekerja di sektor 
pertanian, kehutanan, perburuan dan perikanan. Data ini didukung dengan hasil wawancara yang mendapatkan $12,9 \%$ responden bekerja sebagai buruh tani dan $28,2 \%$ responden ibu hamil ikut kegiatan bertani. Riwayat responden ikut tani meliputi kegiatan penanaman, penyemprotan dengan pestisida dan pemanenan.

Penggunaan pestisida yang berlebihan akan menyebabkan timbal terdeposit dalam tanaman itu sendiri. Pusat Penelitian dan Pengembangan Tanah dan Agroklimat (2003) mencatat akumulasi timbal dalam bawang merah di wilayah Kabupaten Tegal dan Brebes sebesar 0,41 - 5,71 ppm. Nilai ini sudah melebihi ambang batas aman karena menurut Ditjen POM Depkes nilai ambang batas timbal dalam sayuran adalah sebesar 0,24 ppm. ${ }^{15}$ Hal tersebut sesuai dengan penelitian yang dilakukan oleh Hartini pada tahun 2011, ditemukan kandungan $\mathrm{Pb}$ dalam umbi bawang merah di Kecamatan Kersana Kabupaten Brebes antara 0,16 $-0,20$ ppm. $^{16}$

Empat kecamatan yang menjadi wilayah penelitian merupakan jalur pantura. Panjang jalan pantura yang melintas di Kabupaten Brebes $\pm 32,8$ km. ${ }^{17}$ Jalur ini merupakan salah satu jalur transportasi darat yang utama di Pulau Jawa. Tingginya volume kendaraan yang melintas di wilayah ini merupakan salah satu komponen penyumbang pencemaran timbal. Asap kendaraan yang berasal dari sisa pembakaran bahan bakar bensin diketahui mengandung timbal. ${ }^{18}$ Keberadaan timbal di udara ini sedikit banyak akan terhirup oleh manusia termasuk juga ibu hamil di wilayah penelitian. Masyarakat yang tinggal di wilayah padat kendaraan sangat beresiko terpapar timbal. Penelitian yang dilakukan di Kota Surakarta menyebutkan bahwa petugas DLLAJ yang bertugas di terminal tirtonadi terpapar timbal lebih banyak dibanding petugas yang bekerja di dalam kantor, hal ini berhubungan langsung dengan kadar timbal dalam darah para petugas tersebut. ${ }^{19}$

\section{Distribusi Riwayat Ikut Tani dan Riwayat Paparan Asap Rokok}

Saat proses wawancara peneliti juga menanyakan riwayat keikutsertaan ibu hamil dalam kegiatan pertanian dan riwayat paparan asap rokok yang disajikan pada tabel 2 .

Tabel 2. Distribusi Frekuensi Riwayat Ikut Tani dan Riwayat Paparan Asap Rokok

\begin{tabular}{clcc}
\hline No. & \multicolumn{1}{c}{ Variabel } & Frek $(\mathrm{n}=92)$ & $\%$ \\
\hline 1. & Riwayat Ikut Tani & & \\
& a. Ya & 24 & 28,2 \\
& b.Tidak & 59 & 71,1 \\
& Total & 83 & 97,6 \\
2. Riwayat Paparan Asap Rokok & & \\
a.Ya & 67 & 78,8 \\
b.Tidak & 17 & 20,0 \\
Total & 84 & 98,8 \\
\hline
\end{tabular}

Berdasarkan tabel 2 dapat diketahui bahwa ibu hamil yang ikut kegiatan pertanian sebanyak 24 orang $(28,2 \%)$ dan ibu hamil tidak ikut kegiatan pertanian sebanyak 59 orang $(71,1 \%)$. Pada data hasil pertanyaan ini terdapat 2 responden yang tidak menjawab, sehingga terdapat 2 data kosong. Untuk kategori terpapar asap rokok selama kehamilan, ibu hamil yang terpapar asap rokok berjumlah 67 orang $(78,8 \%)$ dan yang tidak terpapar asap rokok berjumlah 17 orang $(20,0 \%)$.
Pada kategori paparan asap rokok ini, 1 responden tidak terisi datanya sehingga total 84 responden yang bisa dianalisis.

\section{Hasil Pemeriksaan Laboratorium Kadar Timbal dan Kadar Malondialdehid dalam Darah}

Pemeriksaan laboratorium dilakukan untuk mengukur kadar timbal dan kadar malondialdehid dalam darah. Hasil pemeriksaan tersebut disajikan dalam tabel 2.

Tabel 3. Hasil Pemeriksaan Laboratorium Kadar Timbal dan Kadar Malondialdehid dalam Darah

\begin{tabular}{clcccc}
\hline No. & \multicolumn{1}{c}{ Variabel } & $\mathrm{n}$ & Rerata (SD) & Median & Min - Max \\
\hline 1. & $\begin{array}{l}\text { Kadar Pb dalam Darah } \\
(\mu \mathrm{g} / \mathrm{dl})\end{array}$ & 85 & $42,67(19,69)$ & 41,8 & $3,6-108,6$ \\
2. & $\begin{array}{l}\text { Kadar Malondialdehid } \\
\text { dalam Darah }(\mathrm{ng} / \mathrm{ml})\end{array}$ & 85 & $377.30(323,70)$ & 253,79 & $0,61-1579,60$ \\
\hline
\end{tabular}

Tabel 3 menunjukkan bahwa ibu hamil yang menjadi subjek penelitian ini memiliki kadar timbal rata-rata 42,67 $\mu \mathrm{g} / \mathrm{dl}$, dengan kadar terendah adalah $3,6 \mu \mathrm{g} / \mathrm{dl}$ dan tertinggi 108,6 $\mu \mathrm{g} / \mathrm{dl}$. Kadar malondialdehid pada ibu hamil memiliki angka rata-rata $377,30 \mathrm{ng} / \mathrm{ml}$, namun angka ini mempunyai rentang yang sangat lebar dimana kadar terendah adalah $0,61 \mathrm{ng} / \mathrm{ml}$ sedangkan kadar tertinggi $1579,60 \mathrm{ng} / \mathrm{ml}$. Ambang batas normal untuk kadar timbal dalam darah adalah $5 \mu \mathrm{g} / \mathrm{dl}$, 
untuk itu data kadar timbal dalam darah dikategorikan menjadi normal dan tinggi dengan cut off point $5 \mu \mathrm{g} / \mathrm{dl}$. Hal yang sama dilakukan untuk kadar malondialdehid dalam darah dengan cut off point $1,04 \mathrm{ng} / \mathrm{ml}$.

Tabel 4. Distribusi Frekuensi Hasil Uji Kadar Timbal dan Kadar Malondialdehid dalam Darah

\begin{tabular}{|c|c|c|c|}
\hline No & Variabel & Frek $(n=84)$ & $\begin{array}{c}\text { Persentase } \\
(\%)\end{array}$ \\
\hline \multicolumn{4}{|c|}{ 1. Kadar timbal } \\
\hline & - Normal & 1 & 1,2 \\
\hline & - Tinggi & 83 & 98,8 \\
\hline \multirow[t]{3}{*}{2.} & Kadar Malondialdehid & & \\
\hline & - Normal & 1 & 1,2 \\
\hline & - Tinggi & 83 & 98,8 \\
\hline
\end{tabular}

Tabel 4. menunjukkan bahwa hanya 1 ibu hamil yang mempunyai kadar timbal normal $(1,2 \%)$ dan sisanya 83 ibu hamil $(98,8 \%)$ mempunyai kadar timbal kategori tinggi. Kategori

Dilihat dari sisi pendidikan, ibu hamil yang menjadi responden penelitian ini sedikit lebih terdidik jika dibandingkan dengan data pendidikan masyarakat brebes secara umum. Hanya terdapat 3 responden yang tidak sekolah, namun jumlah responden yang berpendidikan tamat SD 41 orang $(48,2 \%)$, dan sisanya berpendidikan tamat SMP, SMA, dan perguruan Tinggi. Pekerjaan ibu hamil dan suami diduga juga berpengaruh terhadap resiko paparan timbal, terutama untuk kategori pekerjaan yang rentan terpapar timbal yaitu petani dan buruh tani. Hal ini terkait dengan penggunaan pestisida yang mengandung timbal selama proses bekerja. Hasil wawancara menunjukkan 11 responden berprofesi sebagai buruh tani, dimana mereka melakukan kontak langsung dengan pestisida selama bekerja sehingga meningkatkan potensi terpapar timbal. Beberapa responden tidak berprofesi sebagai petani atau buruh tani, namun mempunyai riwayat ikut kegiatan tani sebanyak 24 responden.

Data hasil pengukuran kadar timbal dalam darah responden cukup fantastis, dari 85 sampel darah yang diperiksa, hanya 1 responden yang

Kadar timbal dalam darahnya di bawah ambang normal $(<5 \mu \mathrm{g} / \mathrm{dl})$, sedangkan 84 responden mempunyai kadar timbal dalam darah yang melebihi normal. Nilai retata kadar timbal dalam darah responden adalah 42,67 $\mu \mathrm{g} / \mathrm{dl}$, jauh diatas batas normal. Kadar timbal dalam darah ibu hamil yang tinggi ini dipengaruhi oleh banyak faktor seperti yang telah diuraikan diatas, yaitu lokasi, pekerjaan, dan sifat dari paparan timbal yang akumulatif seiring waktu.

Kadar malondialdehid dalam darah menggambarkan tingkat stress oksidatif dalam tubuh. Senyawa ini terbentuk dari hasil reaksi peroksidasi lipid melibatkan spesies kimia aktif yang dikenal sebagai radikal bebas. Radikal bebas sendiri dapat berasal dari dua sumber yaitu endogen dan eksogen. Radikal bebas yang bersifat eksogen antara lain berasal dari asap rokok, polusi, kadar malondialdehid dengan cut off point 1,04 $\mathrm{ng} / \mathrm{ml}$ dari $84 \mathrm{ibu}$ hamil, sebanyak $83 \mathrm{ibu}$ hamil $(98,8 \%)$ masuk dalam kategori tinggi dan hanya 1 ibu hamil $(1,2 \%)$ yang terkategori normal.

obat, pestisida, limbah industri, dan ozon. Radikal bebas endogen utama yang diproduksi oleh tubuh adalah radikal derivate oksigen atau oksi-radikal yang sering disebut dengan istilah reactive oxygen species (ROS). Radikal-radikal tersebut terdapat dalam bentuk triplet $\left({ }^{3} \mathrm{O}_{2}\right)$ atau singlet $\left({ }^{1} \mathrm{O}_{2}\right)$, superoksida $\left(\mathrm{O}_{2}^{-}\right)$, radikal hidroksil $\left(\mathrm{OH}^{-}\right)$, nitrit oksida $\left(\mathrm{NO}^{-}\right)$, peroksinitrit $\left(\mathrm{ONOO}^{-}\right)$, asam hidrokloro $(\mathrm{HOCl})$, hydrogen peroksida $(\mathrm{H} 2 \mathrm{O} 2)$, radikal alkoksil $\left(\mathrm{LO}^{-}\right)$dan radikal peroksil $\left(\mathrm{LOO}^{-}\right){ }^{20}$

Penelitian ini mendapatkan 85 sampel darah ibu hamil yang diukur kadar malondialdehid. Hasil pemeriksaan menunjukkan sebaran data yang sangat lebar, kadar malondialdehid dalam darah responden berada dalam rentang $0,61 \mathrm{ng} / \mathrm{ml}$ sampai dengan $1.579,60 \mathrm{ng} / \mathrm{ml}$ dengan rata-rata adalah $253,79 \mathrm{ng} / \mathrm{ml}$. Nilai yang sangat bervariasi ini kemungkinan disebabkan banyaknya faktor yang mempengaruhi produksi malondialdehid.

Kadar malondialdehid dalam darah ibu hamil yang diperiksa pada penelitian ini dikategorikan menjadi normal dan tinggi dengan nilai cut off point sebesar 1,04 1,04 ng/ml. Data menunjukkan bahwa hanya ada 1 ibu hamil $(1,2 \%)$ dengan kadar malondialdehid kategori normal, sisanya sejumlah $84 \mathrm{ibu}$ hamil tergolong dalam kategori tinggi. Hal ini sejalan dengan data kategori kadar timbal dalam darah dimana 84 responden mempunyai kadar timbal yang tinggi. Timbal yang terdapat dalam tubuh berperan sebagai radikal bebas dari sumber eksogen yang menyebabkan stress oksidatif. keberadaan timbal yang tinggi dalam tubuh menyebabkan stress oksidatif yang dapat diukur dengan kadar malondialdehid sebagai senyawa produk stress oksidatif. $^{21}$

\section{Hubungan Kadar Timbal dengan Kadar Malondialdehid pada Ibu Hamil}

Berdasarkan hasil uji normalitas data, uji korelasi yang digunakan untuk variabel kadar timbal dalam darah dengan kadar malondialdehid 
dalam darah adalah uji korelasi Rank Spearman.

tabel 5.

Hasil uji korelasi Rank Spearman disajikan pada

Tabel 5. Hasil Uji Bivariat Antara Variabel Kadar Timbal dalam Darah dengan Kadar Malondialdehid dalam Darah

\begin{tabular}{cccc}
\hline Variabel & $p$ value & r & Kesimpulan \\
\hline $\begin{array}{c}\text { Kadar timbal dalam Darah dengan Kadar } \\
\text { Malondialdehid dalam Darah }\end{array}$ & 0,312 & 0,111 & $\begin{array}{c}\text { Tidak ada } \\
\text { hubungan }\end{array}$ \\
\hline
\end{tabular}

Hasil uji korelasi antara kadar timbal dengan kadar malondialdehid pada ibu hamil menunjukkan bahwa tidak ada hubungan bermakna antara kedua variabel ini ( $p$ value $=0,312 ; \mathrm{r}=0,111)$. Hal ini tidak sejalan dengan teori yang ada yang kemungkinan disebabkan adanya variabel-variabel lain yang tidak bisa dikontrol dalam penelitian ini.

Timbal bukan satu-satunya penyebab stress oksidatif dalam tubuh. Stressor lain seperti radiasi sinar rontgen dan ultraviolet, hipoksia dan hyperoksia, obat, polutan, dan senyawa kimia lain dapat menyebabkan peningkatan produksi ROS. ${ }^{22}$ Faktor-faktor lain tersebut kemungkinan menyebabkan kadar malondialdehid dalam darah responden yang diperiksa menjadi sangat bervariasi sehingga ketika dilakukan uji hubungan dengan kadar timbal dalam darah, kedua variabel tersebut menjadi tidak berhubungan.

Faktor lain penyebab munculnya ROS menjadi variabel pengganggu dalam penelitian. Malondialdehid sebagai senyawa produk stress oksidatif juga disebabkan oleh faktor endogen. Reactive Oxygen Species (ROS) adalah senyawa

\section{DAFTAR PUSTAKA}

1. Dinas Kesehatan Provinsi Jawa Tengah. Profil Kesehatan Provinsi Jawa Tengah. Vol 3511351. Semarang; 2016.

2. Dinas Kesehatan Kabupaten Brebes. Profil Kesehatan Kabupaten Brebes Tahun 2015.; 2015.

3. WHO. Preventing Disease Through Healthy Environments. Exposure To Lead: A Major Public Health Concern. WHO Doc Prod Serv. 2010.

http://www.who.int/ipcs/features/hazardous_p esticides.pdf?ua $=1$.

4. Suksmerri. Dampak Pencemaran Logam Timah Hitam $(\mathrm{Pb})$ Terhadap Kesehatan. $J$ Kesehat Masy. 2008;II(2, September):200202.

5. US Environmental Protection Agency (EPA). Protect your family from lead in your home. 2013;(September):14.

6. Minnesota Department of Health. Blood Lead Screening Guidelines for Pregnant and Breastfeeding Women in Minnesota. 2015; (August).

7. Ettinger A, Wengrovitz AG, eds. Guidelines for the Identification and Management of atau molekul yang mengandung satu atau lebih electron tidak berpasangan pada orbit luarnya, akibatnya senyawa tersebut sangat reaktif mencari pasangan dengan cara mengikat electron molekul yang berada di sekitarnya. Secara alami, proses oksidasi biologis yang terjadi pada sel (jaringan) tubuh manusia yang normal, dapat terbentuk oksigen reaktif atau disebut juga radikal bebas.

\section{SIMPULAN}

Kadar timbal dalam darah pada ibu hamil di lokasi penelitian rata-rata $42,67 \mu \mathrm{g} / \mathrm{dL}$, berkisar 3,6-108,6 $\mu \mathrm{g} / \mathrm{dL}$, sedangkan kadar malondialdehid ibu hamil rata-rata $377,30 \mathrm{ng} / \mathrm{ml}$, berkisar antara 0,61-1579,60 ng/ml. Kadar timbal dalam darah pada ibu hamil di Kecamatan Losari, Tanjung, Bulakamba, dan Wanasari Kabupaten Brebes tergolong tinggi karena melebihi nilai ambang batas $5 \mu \mathrm{g} / \mathrm{dL}$. Dalam penelitian ini, kadar timbal dan kadar malondialdehid dalam darah pada ibu hamil tidak saling berhubungan.

Lead Exposure in Pregnant and Lactating Women. U.S. Department of Health and Human Services; 2010. https://www.cdc.gov/nceh/lead/publications/le adandpregnancy2010.pdf.

8. Sinaga FA. Stress Oksidatif Dan Status Antioksidan Pada Aktivitas Fisik Maksimal. J Gener Kampus. 2016;9(2):176-189. doi:10.1042/BJ20091286.

9. Candra S, Widodo MA, Suwarto S, G IKM. Kadar MDA dan Rasio GSH/GSSH pada Kehamilan Normal, Preeklampsia Berat dan Eklampsia di Malang. J Kedokt Brawijaya. 2007;XXIII(1, April):35-39.

10. Del Rio D, Stewart AJ, Pellegrini N. A review of recent studies on malondialdehyde as toxic molecule and biological marker of oxidative stress. Nutr Metab Cardiovasc Dis. 2005;15:316-328. doi:10.1016/j.numecd.2005.05.003.

11. Kecamatan Bulakamba Dalam Angka 2018. Brebes: BPS Kabupaten Brebes; 2018.

12. Kecamatan tanjung dalam angka 2018. 2018.

13. Kecamatan Wanasari Dalam Angka 2018.; 2018.

14. Suyanto A, Kusmiyati S, Retnaningsih C. 
Residu Logam Berat Ikan dari Perairan Tercemar di pantai Utara Jawa Tengah (Residual Heavy Metals in Fish from Contaminated Water in North Coast of Central Java). $J$ Pangan dan Gizi. 2010;1(2):1-8.

15. Pusat Penelitian dan Pengembangan Tanah dan Agroklimat. Pencemaran Bahan Agrokimia Perlu Diwaspadai. War Penelit dan Pengemb Pertan Indones. 2003;25(6):1314.

16. Hartini E. Kadar Plumbum (Pb) Dalam Umbi Bawang Merah di Kecamatan Kersana Kabupaten Brebes. J Visikes. 2011;10(1):6975.

http://www.dinus.ac.id/wbsc/assets/dokumen/ majalah/Kadar_Plumbun_(Pb)_Dalam_Umbi_ Bawang_Merah_di_Kecamatan_Kersana_Kab upaten_Brebes.pdf.

17. Nugroho U, Sutarto A, Endradewi F, Alisa YN. Evaluasi Kapasitas Ruas Jalan Pantura Kabupaten Brebes. J Tek Sipil Perenc. 2017;19(32):71-76.

18. Gusnita D. Pencemaran Logam Berat Timbal $\mathrm{Pb}$ ) di Udara dan Upaya Penghapusan Bensin Bertimbal. Ber Dirgant. 2012;13(3, September):95-101.

19. Mardani TR, Setiyono P, Listyawati S. Kadar Timbal $(\mathrm{Pb})$ dalam Darah dan Hubungannya dengan Kadar $\mathrm{Hb}$ Darah Akibat Emisi Kendaraan Bermotor pada Petugas DLLAJ di Kota Surakarta. BioSMART. 2005;7(1, April):60-65.

20. Surya IGP. Kadar Malondiadehyde (MDA) Pada Abortus Spontan. Denpasar: Bagian/SMF Obstetri dan Ginekologi FK UNUD/RSUP Sanglah Denpasar; 2013.

21. Euis Reni Yuslianti. Pengantar Radikal Bebas Dan Antioksidan. Yogyakarta: Deepublish; 2018.

22. Widayati E. oxidasi Biologi, Radikal Bebas, dan Antioxidant. Maj Ilm Sultan Agung. 2012;50(128).

https://media.neliti.com/media/publications/22 0034-oxidasi-biologi-radikal-bebas-danantiox.pdf. 